\title{
Macroinvertebrate assemblages in 25 high alpine ponds of the Swiss National Park (Cirque of Macun) and relation to environmental variables
}

\author{
Beat Oertli • Nicola Indermuehle • Sandrine Angélibert • \\ Hélène Hinden · Aurélien Stoll
}

(C) Springer Science+Business Media B.V. 2007

\begin{abstract}
High-altitude freshwater ecosystems and their biocoenosis are ideal sentinel systems to detect global change. In particular, pond communities are likely to be highly responsive to climate warming. For this reason, the Swiss National Park has included ponds as part of a long-term monitoring programme of the high-alpine Macun cirque. This cirque covers $3.6 \mathrm{~km}^{2}$, has a mean altitude of 2,660 $\mathrm{m}$ a.s.l., and includes a hydrographic system composed of a stream network and more than 35 temporary and permanent ponds. The first two steps in the programme were to (i) make an inventory of the macroinvertebrates of the waterbodies in the Macun cirque, and (ii) relate the assemblages to local or regional environmental
\end{abstract}

Guest editors: R. Céréghino, J. Biggs, B. Oertli \& S. Declerck The ecology of European ponds: defining the characteristics of a neglected freshwater habitat

Electronic supplementary material The online version of this article (doi:10.1007/s10750-007-9218-7) contains supplementary material, which is available to authorized users.

B. Oertli $(\bowtie) \cdot N$. Indermuehle · S. Angélibert · A. Stoll Department of Nature Management, University of Applied Sciences of Western Switzerland - EIL, 1254 Jussy, Geneva, Switzerland

e-mail: beat.oertli@hesge.ch

\section{H. Hinden}

Laboratoire d'Ecologie et de Biologie aquatique, University of Geneva, 1206 Geneva, Switzerland variables. Sampling was conducted in 25 ponds between 2002 and 2004. The number of taxa characterising the region (Macun cirque) was low, represented by 47 lentic taxa. None of them was endemic to the Alps, although several species were cold stenothermal. Average pond richness was low (11.3 taxa). Assemblages were dominated by Chironomidae (Diptera), and Coleoptera and Oligochaeta were also relatively well represented. Other groups, which are frequent in lowland ponds, had particularly poor species richness (Trichoptera, Heteroptera) or were absent (Gastropoda, Odonata, Ephemeroptera). Macroinvertebrate assemblages (composition, richness) were only weakly influenced by local environmental variables. The main structuring processes were those operating at regional level and, namely, the connectivity between ponds, i.e. the presence of a physical connection (tributary) and/or small geographical distance between ponds. The results suggest that during the long-term monitoring of the Macun ponds (started in 2005), two kinds of change will affect macroinvertebrate assemblages. The first change is related to the natural dynamics, with high local-scale turnover, involving the metapopulations characterising the Macun cirque. The second change is related to global warming, leading to higher local and regional richness through an increase in the number of colonisation events resulting from the upward shift of geographical ranges of species. At the same time the cold stenothermal species from Macun will be subject to extinction. 
Keywords Zoobenthos - Small waterbodies · Biodiversity · Swiss Alps · Biomonitoring

\section{Introduction}

Ongoing and future global change threatens biodiversity (Thomas et al., 2004) at local, regional and global scales. In this context, it is urgent to put into action long-term programmes, to assess and monitor predicted changes. This type of monitoring has the ability to integrate sentinel ecosystems that can detect signs of stress. Mountain biocoenoses are particularly sensitive to global change (Thuillier et al., 2005), and future climatic warming in Europe is predicted to be greatest in the arctic and alpine regions (Wathne \& Hansen, 1997). High-altitude aquatic ecosystems may be especially sensitive to global change (Theurillat \& Guisan, 2001), and particularly to climate warming (Sommaruga-Wograth et al., 1997; Sommaruga et al. 1999; Gurung, 2005). With their small size and their relatively simple community structure, ponds constitute ideal sentinel and early warning systems (De Meester et al., 2005). This is especially true in alpine environments, where pond communities are speciespoor and simpler than in lowland environments (Hinden et al., 2005). Therefore, high alpine ponds constitute ideal systems for long-term monitoring of global changes.

The Swiss National Park started in 2001 a longterm monitoring programme at the high-altitude "Macun cirque", including the ponds. The Swiss National Park is one of the 28 selected UNESCO Mountain Biosphere Reserves (Scheurer, 2004). The Macun cirque covers $3.6 \mathrm{~km}^{2}$; it has a mean altitude of 2,660 m a.s.l., and includes a large hydrographic system composed of a stream network and more than 35 temporary and permanent ponds. Earlier scientific research in this area is limited, but includes information on diatom communities (Schanz, 1984).

One of the preliminary steps towards monitoring is to establish a large and solid baseline through intense and comprehensive field investigations. Indeed, understanding patterns of biodiversity distribution is essential to conservation strategies (Gaston, 2000), and resolving the relative contributions of local and regional processes might provide a key to understanding global patterns of biodiversity
(Gaston \& Spicer, 2004). As such, various abiotic and biotic investigations were conducted in the Macun cirque (starting in 2001), on all types of waterbodies (Matthaei, 2003; Hinden, 2004; Logue et al., 2004; Ruegg \& Robinson, 2004; Stoll, 2005). The objectives partly followed GLOCHAMORE (Global Change and Mountain Regions) Research Strategy (Gurung, 2005), and aimed to assess the current biodiversity of the cirque, as a requisite before trying to assess or to monitor biodiversity change.

A synthesis of the investigations conducted on the ponds is presented here. The objectives of this article are to (i) present the distribution patterns of the aquatic macroinvertebrates in a network of highalpine ponds, with a special focus on the diversity (alpha and gamma) and the composition of the taxonomic assemblages; and (ii) investigate whether observed patterns are determined by regional or local processes. As the scientific information collected is intended to constitute a baseline for the long-term monitoring of the Macun cirque, a set of questions were addressed to build a coherent monitoring programme. In particular, what taxonomic groups are dominant (density and richness) in these high altitude systems? What taxa can be used for monitoring purposes? Can flagship groups be used for monitoring, as is the case for lowland ponds (e.g. Odonata; Clausnitzer \& Jödicke, 2004)? As a high level of endemism is expected (Väre et al., 2003), should there be any particular species of macroinvertebrates to monitor?

\section{Methods}

Study site

The Macun cirque was added to the Swiss National Park in 2000 and is currently designated for longterm monitoring of Alpine waterbodies. This area is situated in the high alpine zone of the Alps $(>2,600 \mathrm{~m}$ a.s.l.) in Graubünden, Switzerland $\left(46^{\circ} 44^{\prime} \mathrm{N}, 10^{\circ} 08^{\prime} \mathrm{E}\right)$. The climatic conditions are extreme, with extended ice cover ( 9 month). The temperature range is large (from $<-15^{\circ} \mathrm{C}$ in winter to $>20^{\circ} \mathrm{C}$ in summer), and precipitation is low, around $850 \mathrm{~mm} /$ year (Robinson \& Kawecka, 2005). 
Fig. 1 The hydrological system from Macun cirque (Swiss National Park) with the position of the 25 sampled ponds
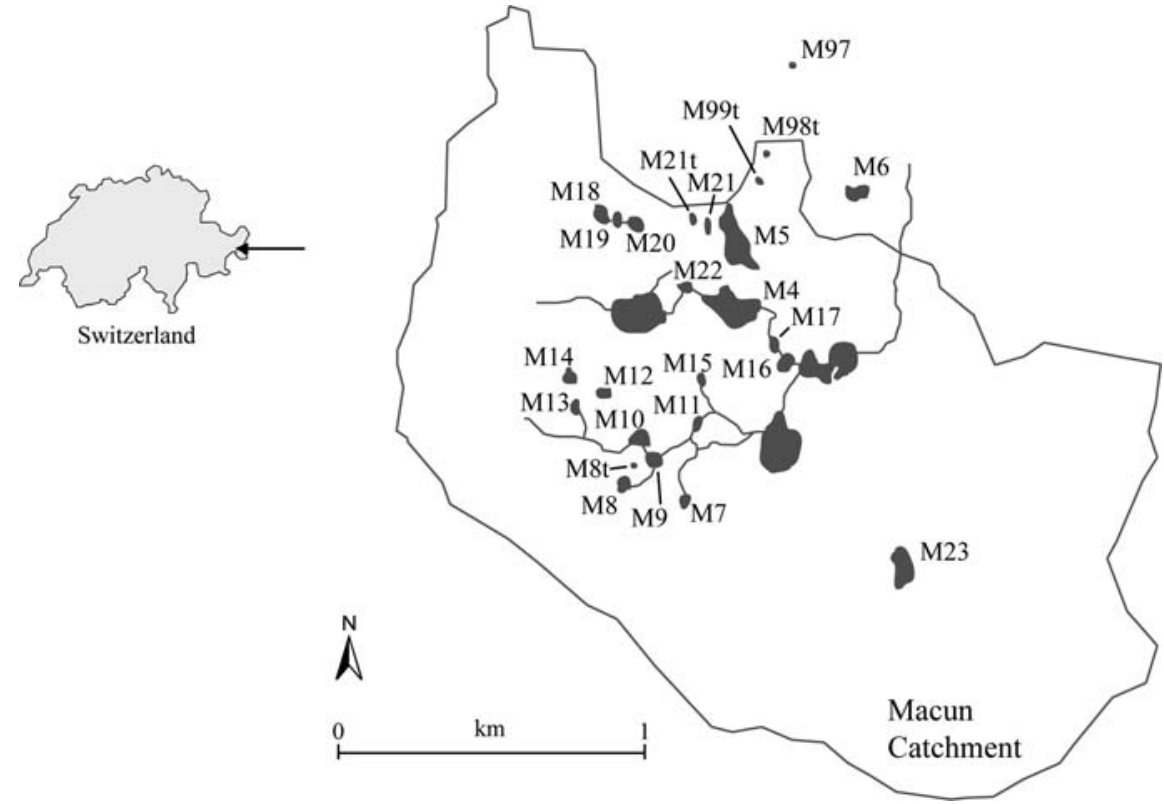

Bedrock geology is crystalline rock. The cirque covers $3.6 \mathrm{~km}^{2}$ and includes a hydrographic system (Fig. 1) composed of a stream network, more than 35 small waterbodies (area: 24-18,000 $\mathrm{m}^{2}$ ), some of the smallest being temporary. All these waterbodies can be termed "ponds", according to definition in Oertli et al. (2005b): an area less than 2 ha and maximum depth less than $8 \mathrm{~m}$ (except one pond, with a 10-m depth), offering water plants the potential to colonise almost the entire pond area. Some of these ponds are interconnected by streams. The hydrographic system has a natural origin with an age exceeding 4,000 year (the date of the last glacial retreat). The origin of the water differs depending on location in the Macun cirque. Robinson \& Kawecka (2005) differentiated a north basin fed primarily by precipitation (mostly snow) and groundwater and a south basin fed mostly by glacial melt from rock glaciers. The different origin in each basin affects the physico-chemical characteristics of the water (Robinson \& Matthaei, 2007). The south basin had temperatures on average $4^{\circ} \mathrm{C}$ cooler and nitrate- $\mathrm{N}$ levels twice the amount found in the north basin. In contrast, the north basin had higher levels (2-4 times more) of particulate-P, particulate- $\mathrm{N}$, and particulate organic matter than the south basin.

The drainage area of each pond is characterized by a mixture of two types of land cover, rock and alpine grassland (typology following Delarze et al., 1998); land cover was assessed through field survey and the help of GIS (for the delimitation of the drainage area of each pond). From the 35 waterbodies, a subset of 25 was selected for sampling (Fig. 1). The choice included all types of waterbodies: different size, different duration (ponds with a low depth were temporary, dry in August), location in the North or South basin, and connected or not to streams. The $\mathrm{pH}$ of the sampled ponds was acid or near neutral (5.5-7.5).
Table 1 Description of the continuous environmental variables characterising the 25 sampled ponds

${ }^{\text {a }}$ Measured on a subset of 16 ponds

\begin{tabular}{llllll}
\hline & Mean & SD & Median & Minimum & Maximum \\
\hline Altitude (m a.s.l.) & 2641 & 49 & 2653 & 2480 & 2714 \\
Pond area $\left(\mathrm{m}^{2}\right)$ & 1909 & 3139 & 607 & 24 & 12750 \\
Mean depth $(\mathrm{m})$ & 0.99 & 1.08 & 0.60 & 0.05 & 4.50 \\
Max depth $(\mathrm{m})$ & 2.2 & 2.7 & 1.3 & 0.1 & 10.0 \\
Conductivity $(\mu \mathrm{s} / \mathrm{cm})$ & 9.7 & 13.3 & 6.6 & 1.7 & 68.3 \\
Alpine grassland in drainage area $(\%)$ & 56 & 30 & 60 & 5 & 100 \\
Total nitrogen $(\mathrm{mg} / \mathrm{l})^{\mathrm{a}}$ & 0.24 & 0.09 & 0.23 & 0.13 & 0.50 \\
\hline
\end{tabular}


A description of pond morphometry and other selected physico-chemical characteristics is presented in Table 1. Substrate of the ponds was relatively homogeneous (stone, gravel, sand, and occasionally bryophytes) and the habitats available to macroinvertebrates not diverse. Five of the sampled ponds (M4, M5, M14, M16, M17) had fish (Salmo trutta fario, Salvelinus namaycush, Phoxinus phoxinus), and were last stocked in 1993. Information of fish presence was collected by net-fishing and visual observation (Rey \& Pitsch, 2004).

\section{Macroinvertebrate sampling}

The 25 ponds were sampled, either in 2002 (16-22 July) or in 2004 (27 July to 2 August). The standardised procedure "PLOCH" (Oertli et al., 2005a) was used for sampling macroinvertebrates. They were collected with a small-framed hand-net (rectangular frame $14 \times 10 \mathrm{~cm}$, mesh size $0.5 \mathrm{~mm}$ ). For each sample, the net was swept through the water intensively for $30 \mathrm{~s}$. The number of samples taken ranged from 2 to 20 , depending on pond size. Sampling was stratified for the dominant habitats (from the land-water interface to a depth of $2 \mathrm{~m}$ ): stones, gravel, sand and bryophytes. In all cases, the collected material was preserved in $5 \%$ formaldehyde and then comprehensively sorted in the laboratory. Specimens were identified to species level for most taxonomic groups and counted. Chironomidae and Oligochaeta were identified to species level for a subset of 20 ponds. Pupae were generally not considered; nevertheless some were identified when species level identification was impossible for larvae (see Electronic supplementary material). Collected taxa were classified either as lentic or lotic (see Electronic supplementary material). This separation was first made on the basis of ecological information available (Tachet et al., 2000; and for Chironomidae, B. Lods-Crozet personal communication). Nevertheless, some taxa known as lotic were classified as lentic if they were observed in abundance in the isolated ponds (not connected to a tributary).

Data analysis

Invertebrate data used for analysis included only the lentic taxa from the 25 sampled ponds. Lotic taxa whose presences were linked to drift from tributaries (e.g. Plecoptera and Diptera Simuliidae) were discarded (see list in Electronic supplementary material). Each analysis was conducted for both datasets; i.e. the 20 ponds where all macroinvertebrates have been identified and the 25 ponds, where Oligochaeta and Chironomidae were excluded.

Tests were conducted to check inter- and intra-year variability in the composition of the macroinvertebrate assemblage. Four ponds were sampled in both years (2002 and 2004), and one pond was sampled twice in 2004 (27 July and 2 August). Thereafter, all 30 macroinvertebrate assemblages ( 25 ponds, and 5 replicates) were submitted to a Ward clustering. This classification highlighted a very close grouping of the different replicates and demonstrated that differences in assemblage were minor between years (2002-2004) or within year (interval of 6 days). Therefore, for further data analyses, the ponds sampled in 2002 were added to those sampled in 2004 for constitution of a unique dataset.

The true regional diversity (gamma diversity, for the Macun cirque) was estimated through the use of the non-parametric estimator Jackknife-1 (Foggo et al., 2003; Magurran, 2003). This estimator is designed to overcome sample-size inadequacies and to estimate how many species are actually present in sampled habitats (Rosenzweig et al., 2003). Calculations were made with EstimateS software (Colwell, 2005).

Associations between seven environmental variables (mean and max depths, area, altitude, land cover, conductivity and total nitrogen) and taxonomic richness were tested by simple correlation analyses (Spearman correlation test). Three other variables are described by class (presence of tributary connected to another upstream pond, presence of fish, northern or southern position in the cirque) and their relationships with taxonomic richness were assessed by a nonparametric Mann-Whitney test.

To test the influence of environmental variables on the distribution of species, we first performed a Correspondence Analysis (CA). This analysis was realised on presence/absence data on the basis of the species list presented in Electronic supplementary material (but the rarest species, i.e. present in $<5 \%$ of sites, were removed). This procedure was conducted with the whole macroinvertebrate community (20 ponds), as well as after removal of the Oligochaeta and Chironomidae ( 25 ponds). 
Then we tested whether the environmental variables were significantly correlated to the first and/or second axis of the CA. To clarify the interpretation of the CA, we performed a cluster analysis based on Jaccard's index. As the same patterns were observed in both cases, we will present here only the results for the 25-pond dataset. These analyses were done with the Vegan Package (available at http://www. r-project.org), a contributed package for the R environment. Ward's clustering technique was used for identifying different types of assemblages based on abundances transformed into classes (detailed in Electronic supplementary material). Both datasets (20 and 25 ponds) were analysed separately.

\section{Results}

Biodiversity of the Macun ponds

The sampling of the 25 Macun cirque ponds between 2002 and 2004 yielded 57 taxa, most of which were identified to species level (Electronic supplementary material). Ten of these taxa are known as lotic (Electronic supplementary material) and were represented only in waterbodies connected to streams (i.e. drift organisms). With the removal of these lotic taxa, the regional richness (Macun cirque) was 47 lentic taxa. Taxa accumulation reached an asymptote (Fig. 2), indicating that this observed value is near the true value of richness to be expected for the cirque. Furthermore, the Jackknife-1 estimator of true

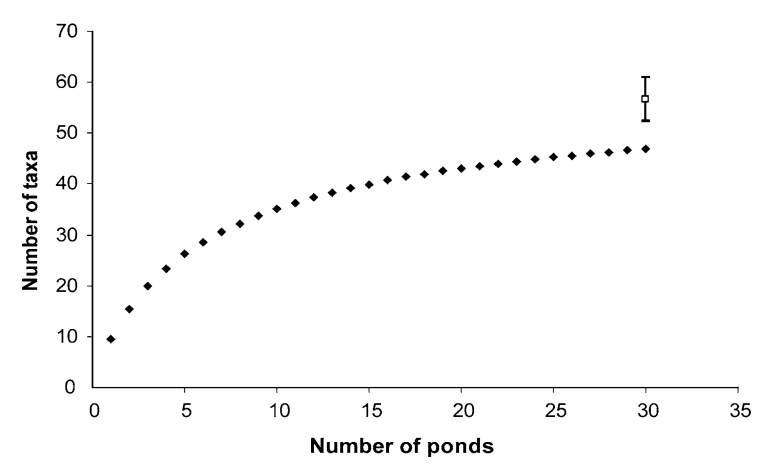

Fig. 2 Accumulation curve for observed richness (S observed) of lentic taxa of the Macun cirque ponds and estimation of true richness ( $S$ true) with estimator Jackknife-1 ( \pm standard deviation: SD). The 30 samples are composed of 25 ponds, three being sampled twice and one being sampled three times richness gives a value of 57.7 taxa $( \pm 4.3)$, suggesting that few taxa were missed (probably about 11) and indicating that the sampling procedure used was efficient for the estimation of regional diversity.

The richest group was the Diptera (25 Chironomidae taxa; five other families), followed by the Oligochaeta (6 taxa) and the Coleoptera (six species). Other represented groups were less diverse: Trichoptera (two species); and Heteroptera, Tricladida, and Bivalvia (each with one species). In terms of abundance (number of individuals), four groups clearly dominated (Electronic supplementary material): Chironomidae, Coleoptera, Oligochaeta and Trichoptera.

This assemblage of 47 lentic taxa is species poor compared to lowland ponds (see taxa list compiled for Swiss lowland ponds by Oertli et al., 2000). For example Hydridae, Hirudinea, Crustacea, Gastropoda, Lepidoptera, Megaloptera, Ephemeroptera, Odonata and Hydracarina are missing.

In order to assess the magnitude of the Macun cirque richness at a larger regional scale, the family Dytiscidae (Coleoptera) was chosen. This choice was motivated by the availability of relatively good knowledge of their geographical distribution in Switzerland (data bank from the Swiss Centre for Faunistic Cartography, and unpublished data from G. Carron) and in Europe (Illies, 1978). The observed species richness for lentic Dytiscidae was five species for the Macun cirque, whereas the Jackknife-1 true richness estimator indicates six species $( \pm 1)$. On a regional scale, the species pool for the Swiss oriental Alps (area: about $8,000 \mathrm{~km}^{2}$ ) is 15 species (G. Carron, personal communication), while the pool for the whole Alps (area: about $100,000 \mathrm{~km}^{2}$ ) is 22 species (data from Illies, 1978). Therefore, taking into account the small area of the Macun cirque (only $3.6 \mathrm{~km}^{2}$ ), the Dytiscidae community is relatively rich.

\section{Endemism of the Macun macroinvertebrates}

Endemism of the macroinvertebrates collected in the Macun cirque was assessed for 30 lentic species based on their biogeographical distribution in Europe (Illies, 1978): none are endemic to the Alps (Fig. 3). Nevertheless, one species, the trichopteran Acrophylax zerberus, is restricted to only four biogeographic 


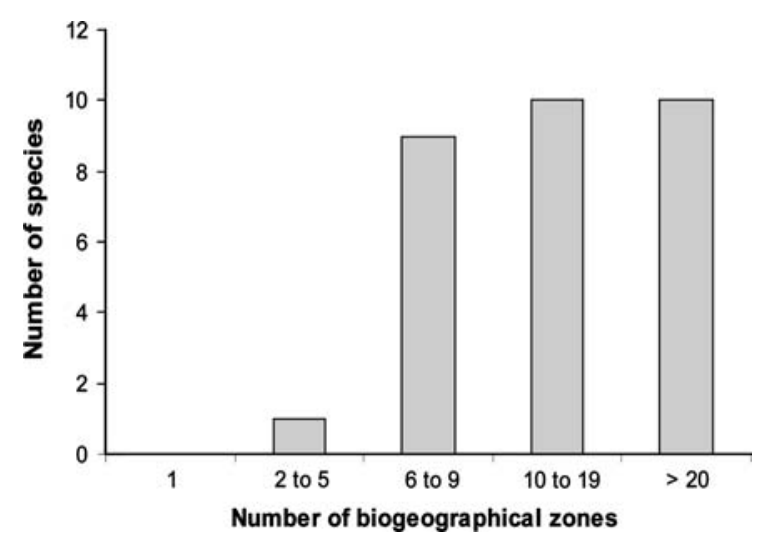

Fig. 3 Geographical distribution in Europe of 30 lentic species collected in the ponds from the Macun cirque. The number of biogeographical zones occupied by each species has been assessed through the information presented in Illies (1978), completed through the expertise of different taxonomy specialists (G. Carron, personal communication; B. LodsCrozet, personal communication; V. Lubini, personal communication)

zones in Europe and can be considered as nearendemic. Some other species, occupying several biogeographic zones (being neither endemic nor near-endemic), are nevertheless restricted to the coldest areas of these zones. This is the case for two Dytiscidae Hydroporus foveolatus and H. nivalis and two Chironomidae Micropsectra notescens and Pseudosmittia oxoniana. These species are cold stenothermal.

Taxa richness in ponds and in samples

Richness of lentic taxa was on average 11.3 taxa per pond (min: 6; max: 24). Chironomidae was the richest group (4.8 taxa per pond), followed by the Coleoptera (2.3) and the Oligochaeta (1.9) (Fig. 4). In the case of Coleoptera, mean species richness per pond is in the range of what has been observed in ponds of the alpine belt in Switzerland (Fig. 5a). However Macun ponds appear species-poor compared to ponds situated at a lower altitude, especially to the $5 \times$-richer ponds from the colline altitudinal belt. The mean richness per sample shows weaker differences. A sample (30 s sweeping with the handnet) taken in a Macun pond gathers a mean Coleoptera richness of 0.93 species $( \pm 0.56)$, a value that is higher than data observed in alpine and even in subalpine ponds (Fig. 5b). The ratio of sample

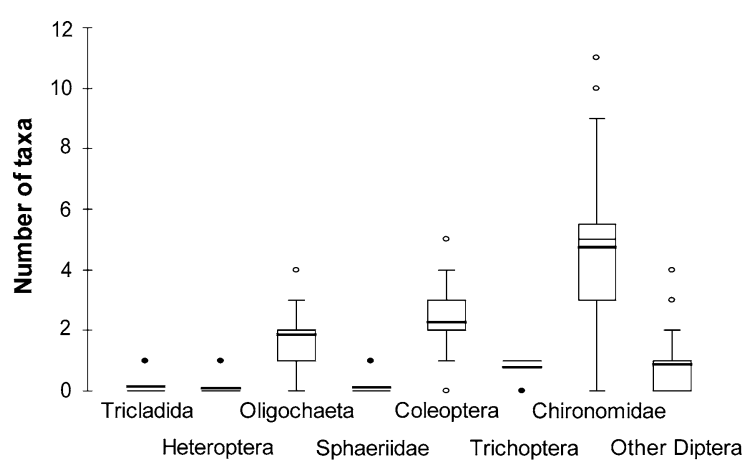

Fig. 4 Mean richness of lentic taxa per pond. Most taxa have been identified to species (see Electronic supplementary material). $n=25$ ponds; except for Chironomidae and Oligochaeta, where $n=20$. Each box represents the interquartile range (IQR, 25-75\%) with the horizontal lines indicating the median (normal line) and the mean (bold line). Upper error bars indicate the non-outlier maximum. Lower error bars indicate the non-outlier minimum. Plain circles indicate outliers $>3 \times$ IQR, empty circles indicate outliers $<3 \times$ IQR

richness to pond richness illustrates the magnitude of the distribution of the species in a given pond. If species are distributed over the whole pond area (and are found in all habitats), each sample will collect all species. On the other hand, if species are restricted to some habitats, a sample will collect only a subset of the whole pond community. The ratio of 0.4 in Macun (mean from across all ponds) indicates that it is possible to catch about $40 \%$ of pond diversity with only one sample. Ratios observed elsewhere in Switzerland are usually much lower, and for all four altitudinal belts they were $\sim 0.15$ (Fig. $5 \mathrm{c}$ ). The high ratio for Macun indicates that the species have a homogeneous distribution inside each of the Macun ponds.

Relation between taxonomic richness and environmental variables

Most of the relationships between lentic taxa richness in ponds and the environmental variables were not significant (at $P=0.05$ ) (Table 2). Taxa richness is related with neither pond area nor altitude. Furthermore, temporality (expressed here by mean depth) also was not a significant variable. Nevertheless, two significant relationships were found. The clearest relationship shows that the presence of a tributary (in connection with a pond situated upstream) significantly enhances the number of lentic taxa in a pond, 

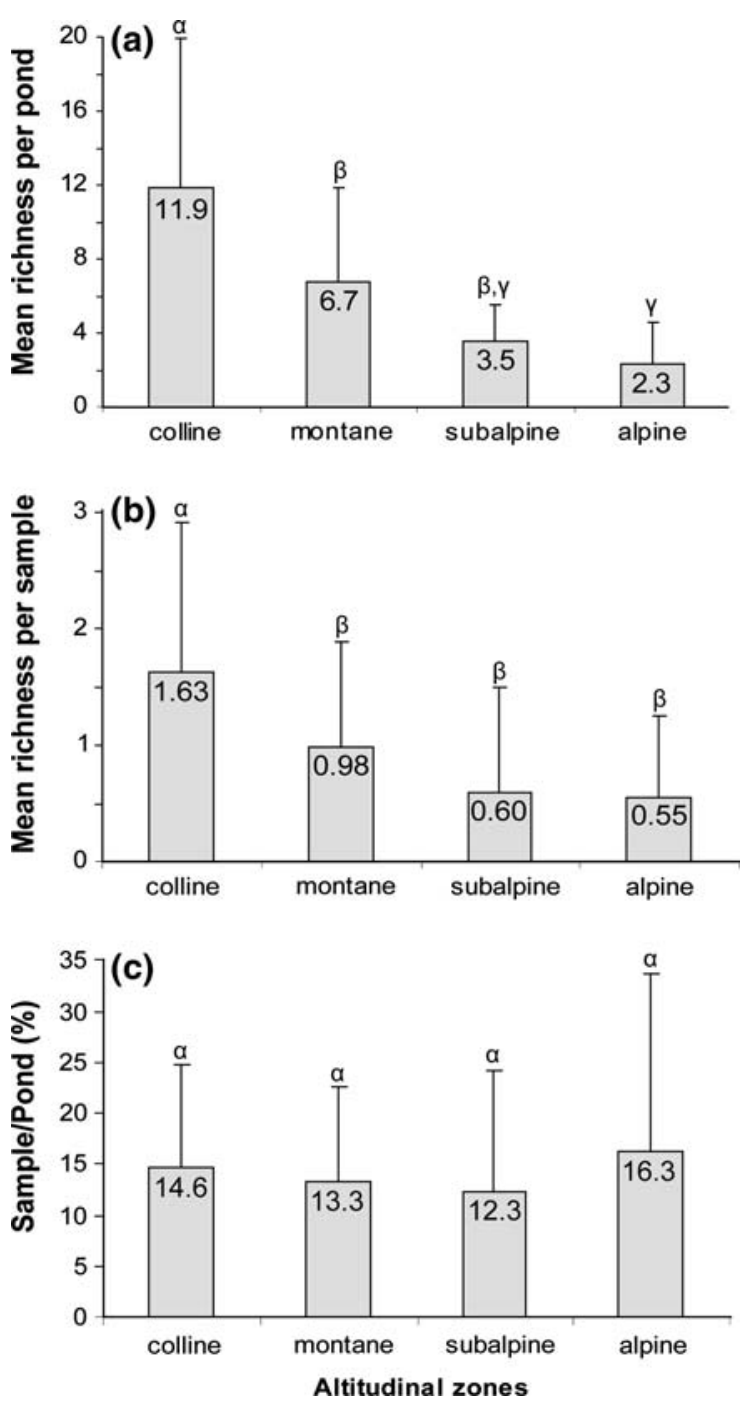

Fig. 5 Mean richness of aquatic Coleoptera per pond (a), per sample (b), and ratio sample/pond (c). Bars with the same letters $(\alpha, \beta$ or $\gamma)$ are not significantly different (MannWhitney, $P>0.05$ ). $n=82$ ponds (data from Oertli et al., 2000) spread throughout the four altitudinal zones of Switzerland: colline (210-665 m a.s.l.; $n=34)$, montane (610$1400 \mathrm{~m}$ a.s.l.; $\quad n=26), \quad$ subalpine $\quad(1410-1988 \mathrm{~m}$ a.s.l.; $n=10)$ and alpine (1860-2650 m a.s.l.; $n=12)$ were sampled with the same standardised procedure PLOCH (Oertli et al., 2005a)

by about $50 \%$. Mean richness increases from 9.5 $( \pm 2.5)$ to $14.1( \pm 5.9)(P=0.03)$ when a tributary is present. When Oligochaeta and Chironomidae taxa are removed, the increase is from $3.6( \pm 1.4)$ to 5.6 $( \pm 2.4)(P=0.01)$. When richness of active colonisers is separated from richness of passive colonisers, the relationship with the presence of a tributary is

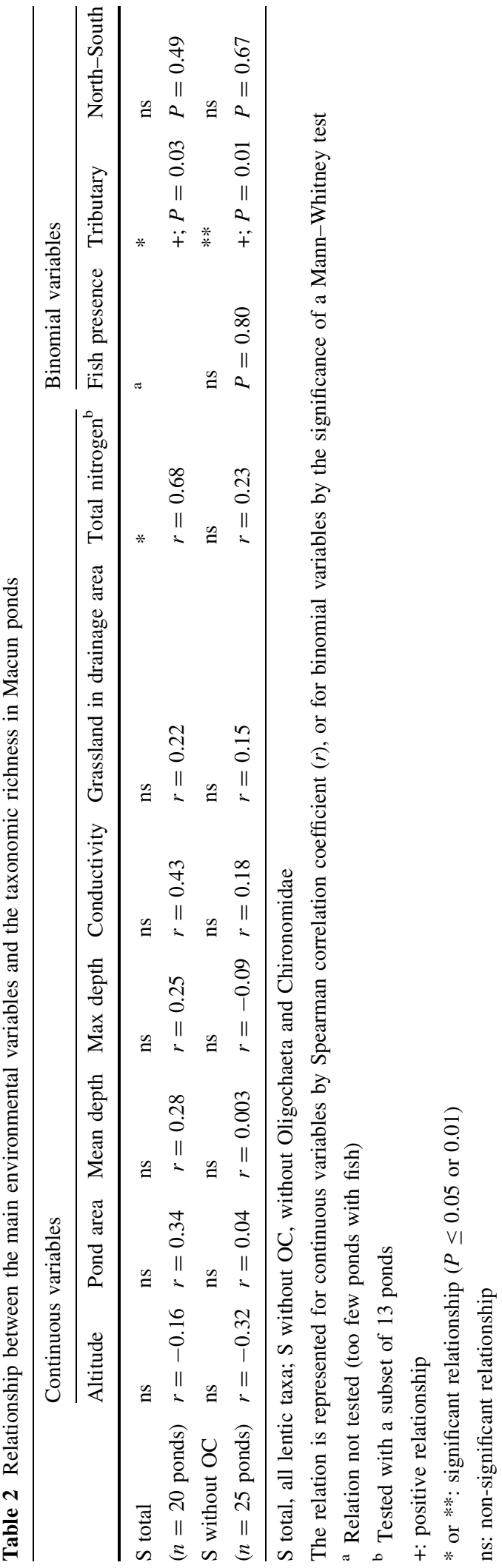


significant in the case of passive colonisers $(P=0.01)$, and near significant with active colonisers $(P=0.06)$. For example, lentic Coleoptera (active colonisers) present a higher richness $(2.8 \pm 1.0)$ in ponds with a tributary than in those without a tributary $(2.0 \pm 1.0)(P=0.03)$.

The other significant relationship shows the positive effect of total nitrogen on taxa richness. However, this relation is dominated by the Chironomidae and Oligochaeta and no more significant when these groups are removed.

Relation of macroinvertebrate assemblages with environmental variables

At first a CA was performed to explore the distribution of species among the ponds and to represent graphically the grouping of the 25 macroinvertebrate assemblages (Fig. 6). The first three axes of the CA explained $26 \%, 17 \%$ and $13 \%$ of the variance, respectively. No significant correlation was found between the measured environmental variables and the first two axes of the CA $(P>0.05$, after 1,000 random permutations of the data).

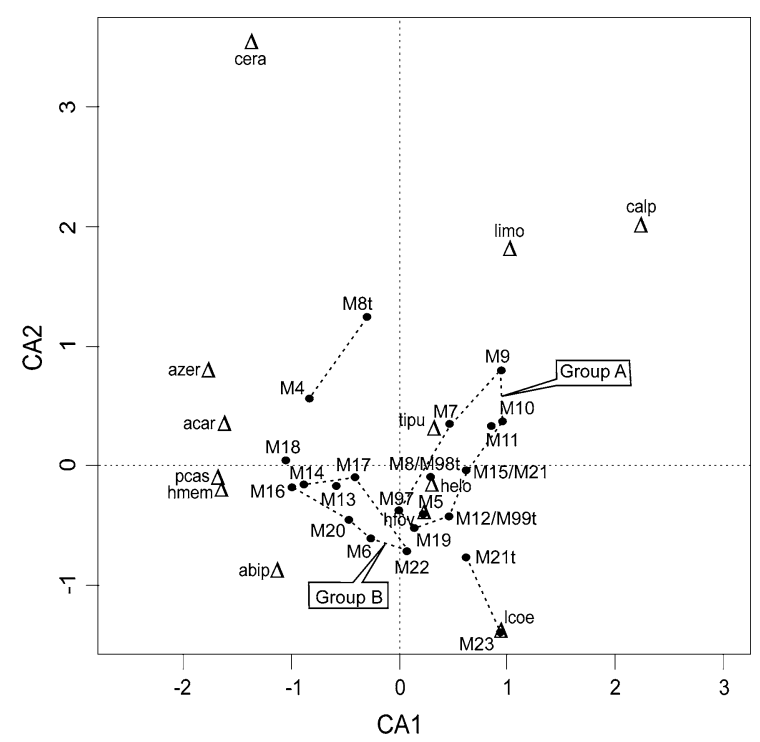

Fig. 6 Correspondence Analysis plot of the macroinvertebrate assemblages (presence/absence data) of 25 ponds from the Macun cirque. Results of clustering (using Jaccard's index; average linkage) is indicated with a dotted line. Species are represented by codes (see list in Electronic supplementary material)
Ordination of sites on the CA plot can be interpreted by the presence of species in each assemblage. Among the most common species, both Trichoptera species played a major role in the ordination of sites. Acrophylax zerberus (present in $28 \%$ of ponds) and Limnephilus coenosus (present in $52 \%$ of ponds) were never found in the same pond. Ponds which supported A. zerberus (M4, M8t, M13, M14 and M16 to M18) are all located on the left side of the CA plot, and ponds which supported L. coenosus were mostly located below in the right part of the CA plot (M6, M10 to M12, M15, M19 to M23, M97 and M99t).

The geographical distance between ponds seemed to influence the distribution of fauna. For example, among the 12 ponds of group A (Fig. 6), seven (M7M12 and M15) are situated very close to each other in the south-western part of the cirque (see Fig. 1). In the same way, neighbour ponds M17-M16 and M13M14 had similar faunal compositions. Results obtained using the 20-pond data set (including Oligochaeta and Chironomidae) showed the same trend (not presented here). A strong similarity among M9, M10 and M11 was also found (Fig. 6). Moreover, the similarity between M13 and M14, and M17 and M16, was stronger than in the 25-pond dataset.

An additional analysis, still with the objective of identifying groups of pond assemblages, but this time taking into account the abundances of the species, was done (Ward's clustering technique). The clustering of the 25 ponds produced three groups (Fig. 7). Taxa driving this clustering were the two species of Trichoptera (Acrophylax zerberus, Limnephilus coenosus) and one species of Coleoptera (Agabus bipustulatus). A. zerberus was present and abundant in all 6 ponds from group A, absent in ponds from group $\mathrm{B}$, and present only once in group C. L. coenosus was absent from group A, present only once in group $\mathrm{B}$, and present and abundant in almost all ponds from group C. A. bipustulatus was present in all ponds from group A but none of group B, and was present in 4 of 15 ponds from group C. None of the local environmental variables (list in Table 2) explained this clustering (Mann-Whitney tests between groups of values). Several ponds belonging to the same cluster are situated geographically close to each other in the cirque; this is the case for: (i) M8, M9 and M10, (ii) M4, M16 and M17, (iii) M13 and M14. 
Fig. 7 Ward's Clustering of the macroinvertebrate assemblages (abundance data) of 25 ponds from the Macun cirque. These assemblages do not include Oligochaeta and Chironomidae

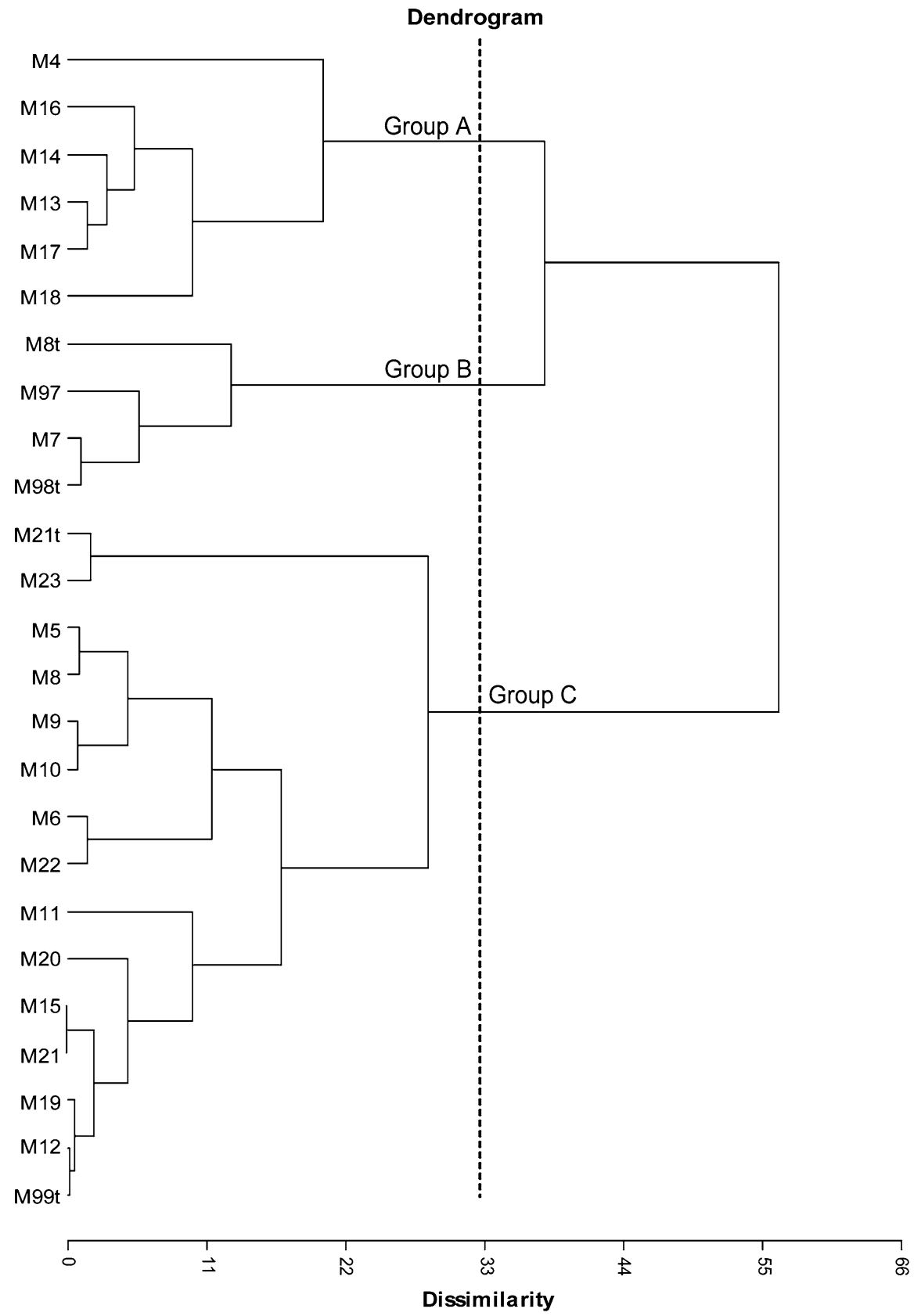

The clustering of the 20 ponds dataset (not presented) produced three groups. The same taxa are driving the clustering as described above. Among the environmental variables, the importance of pond morphology was highlighted, and two groups differed with regard to pond area $(P=0.019)$ and mean depth $(P=0.06)$. The other environmental variables did not influence the clustering.

\section{Discussion}

Biodiversity of the Macun cirque

The number of macroinvertebrate taxa characterising local (pond) or regional (Macun cirque) diversity investigated in this high alpine pond network was low. This was particularly obvious in comparison to 
lowland ponds: for example, alpine ponds hold five times fewer Coleoptera species.

Low richness in Macun has, nevertheless, to be put into perspective. When compared with other alpine ponds, Macun ponds have similar pond richness and even higher sample richness. Furthermore, regional richness (for Macun cirque) was relatively high, including nearly half of the species pool of lentic Dytiscidae from the Swiss oriental Alps. From this point of view, Macun cirque can be considered as a species rich area. This richness is perhaps related to the old age of the Macun ponds ( $>4,000$ years), enabling multiple colonisation events. This high regional richness for the Macun cirque is in agreement with Körner (2001) who underlined the extensive biodiversity of the alpine ecosystems when related to the small surface area of the alpine zone. Väre et al. (2003) stressed the high level of endemism of plants in the Alpine life zone. From this viewpoint, the Macun macroinvertebrate community does not show the same trend, as no endemic species were identified. Nevertheless, many species were cold stenothermal. Indeed, even with a broad geographical distribution in Europe, they are restricted to the coldest areas in each country.

Relation of macroinvertebrate assemblages with environmental variables

The richness of lentic taxa from the Macun ponds was correlated with only a few environmental variables. A clear relationship was demonstrated only with the presence of a tributary (connected with an upstream pond), relating to a regional process. The presence of a tributary greatly enhanced the lentic taxa richness of ponds, by about $50 \%$. This enrichment involved active and passive colonisers, indicating that a tributary enhances the connectivity for both types of colonisers. Most likely, a tributary ensures a continuous supply by drift of individuals living in the connected pond upstream. A tributary could also act as a corridor for migration of the adult stages of insects. Migration of lotic invertebrates in streams has already been well documented (e.g. Soderstrom, 1987; Delucchi, 1989), and lotic dispersal has also been demonstrated for lentic invertebrates (Van de Meutter et al., 2006). Our results are consistent with this last study which indicates that flying and non-flying invertebrates disperse with equal frequency. The magnitude of the enrichment through a tributary was particularly significant in the Macun ponds.

Some local variables generally recognised as important driving factors of pond biodiversity were not significant factors in the Macun ponds. This was the case for pond area, shown elsewhere as a major determinative factor (Oertli et al., 2002). However, Hinden et al. (2005) also did not find significant correlations of area with species richness for a set of alpine ponds spread throughout Switzerland. This absence of relation might be a characteristic of alpine ponds. It can reflect a weak influence of local factors, in particular biotic factors (such as competition and predation). Water chemistry (conductivity and total nitrogen) also was not a strong discriminating local variable, probably because the differences in the chemical characteristics were relatively moderate among the ponds. Nevertheless, chemical differences explain differences in the assemblages of lotic and lentic diatoms in the Macun network (Robinson \& Kawecka, 2005).

As the Macun ponds with a low depth are dry during some weeks in summer, water permanence could be expected to be a key variable explaining richness or species assemblage, as this was already observed for Macun streams (Ruegg \& Robinson, 2004). This was not the case for pond taxa richness. Furthermore, these ponds with a low depth (temporary ponds) did not have species assemblages which were different to those in permanent ponds. At lower altitudes, below the tree-line but still in the mountain zone, duration of water permanence seems to be a much stronger factor; e.g. in subalpine ponds in Colorado (Wissinger et al., 1999) or snowmelt ponds in Wisconsin (Schneider, 1999). A clear negative relationship was demonstrated with species richness, and hydroperiod length influenced community structure. For lowland ponds, this strong structuring effect of hydroperiod duration has already clearly been found (e.g. Wiggins et al., 1980; Williams, 1987; Collinson et al., 1995).

Ponds situated at a small geographical distance from one another tended to have similar macroinvertebrate assemblages. Such positive spatial autocorrelation of community composition is frequently observed in pond networks, at small and large spatial scales (see Briers \& Biggs, 2005). As the 
tested local variables were of relatively weak importance for driving the species richness or the species assemblage, with probably also little pressure from predation or competition, then regional processes and particularly colonisation events should have a high chance of success, therefore playing a major role to explain the distribution of fauna. Furthermore, chance events (Jeffries, 1988) are perhaps an influential factor in these Macun ponds.

In conclusion, assemblages from ponds (composition, richness) are only weakly influenced by local environmental variables in the Macun cirque, and the main structuring processes are regional and namely the connectivity between ponds (physical connection through tributaries and/or small geographical distances among ponds). The situation is undoubtedly different from the lowlands: even in highly interconnected ponds, local environmental constraints can be strong enough to structure local communities (Cottenie et al., 2003).

\section{Monitoring macroinvertebrates in the Macun ponds}

Information collected during the sampling of the 25 Macun ponds gave some useful practical recommendations for the long-term monitoring of the area (Hinden et al., 2005; Stoll, 2005). As proposed by these authors, the PLOCH sampling methodology (Oertli et al., 2005a) must be adapted for this particular species-poor environment. First, the proposed sampling must be more intense for each pond, with a longer duration for each individual sample (double time of sweeping with handnet, from 30 to $60 \mathrm{~s}$ ). Second, sorting of the macroinvertebrates must separate all taxonomic groups (not only Gastropoda and Coleoptera). In particular Oligochaeta and Chironomidae, often neglected, are species-rich if compared with other invertebrate groups. At 26 species, the Chironomidae represent more than half of the taxonomic richness of the lentic macroinvertebrates of the Macun cirque. During monitoring and in particular the data analyses, particular attention should be given to the cold stenothermal species, for example Dytiscidae Hydroporus foveolatus and H. nivalis, Chironomidae Micropsectra notescens and Pseudosmittia oxoniana and Trichoptera Acrophylax zerberus. The dynamics of the populations of such species can potentially give fingerprints of global change. Other particular attention should be given to flagship species or groups. The Odonata, often included in monitoring of lowland waterbodies, are missing in Macun. Even with rapid global warming, this group will stay species-poor for many more years, as relatively a few species comprise the alpine species pool (Maibach \& Meier, 1987). As such, Coleoptera could constitute an alternative flagship group for alpine ponds. This group is well diversified in Macun, has a relatively well-known species distribution in Switzerland and is of some general interest to people.

Expected temporal changes of the species assemblages in the Macun ponds

As the ponds from Macun have low species richness, and as chance events are possibly the most influential structuring factor, each pond is the subject of colonization events that will be frequently successful. Many populations of lentic taxa from Macun vary in time and space in terms of size, and may be subject to local extinction. Therefore, they should be considered as metapopulations (see Bohonak \& Jenkins, 2003) in this connected network of ponds. This would mean that species turnover is high in each Macun pond, and is consistent with Jeffries (2005) who suggests that considerable invertebrate dynamics occur in space and time, a phenomenon not adequately addressed by extensive single-year surveys.

Besides these natural changes due to metapopulation dynamics in the Macun area, other biological changes are expected to occur in the future and are related to global warming. Trends predict an upward shift of geographical ranges of species (Hodkinson \& Jackson, 2005), resulting in colonisation events in the Macun ponds from species present at lower altitudes (i.e. actually present under tree-line). Many of these colonisation events will be successful in these species-poor systems, and will increase regional and local richness. Figure 5a can be used as a prediction of the magnitude of the resulting changes expected at the local scale. The alpine system will, in the future, resemble the subalpine system more and more. The remaining uncertainty in this prediction is the time needed to reach such a situation. Colonisation events take time, and global change involves not only 
changes in temperature, but also changes in duration of ice cover and hydrological functioning, that are much more difficult to predict and model than temperature change. Besides this increase in richness, extinction events will also occur in Macun, and the first victims will probably be the cold stenothermal species.

In conclusion, during the long-term monitoring of the Macun ponds (started in 2005), two types of change will affect the macroinvertebrate species assemblages. The first type of change is related to the natural dynamics occurring in these species-poor systems, with important local-scale turnover, involving the species pool characterising the Macun cirque. The second type of change is related to global warming and will lead to higher local and regional richness, but also to extinction of cold stenothermal species. One of the challenges of monitoring will be to identify these changes and their relationship with natural dynamics and global warming.

Acknowledgements This work was partly supported by the Research Committee from the Swiss National Park. Thanks to Thomas Scheurer and Flurin Filli for logistic support and to everyone who helped in the field-Nathalie Menetrey, Lionel Sager, Zoé Fleury and Marianna Massa. Special thanks to Chris Robinson for his helpful collaboration and also for his constructive review of the manuscript. A large part of the chemical analyses were realised by the Swiss Federal Institute of Aquatic Science and Technology. We are very grateful to the CSCF for access to the Swiss databanks on fauna. Help in identification was provided by Gilles Carron (Coleoptera), Brigitte Lods-Crozet (Chironomidae), Narcisse Giani (Oligochaeta), Verena Lubini (Trichoptera) and Nigel Thew (Sphaeriidae). Also, Jane O'Rourke and Mericia Whitfield are thanked for improving the English style. The constructive comments of two anonymous referees improved the paper.

\section{References}

Bohonak, A. J. \& D. G. Jenkins, 2003. Ecological and evolutionary significance of dispersal by freshwater invertebrates. Ecology Letters 6: 783-796.

Briers, R. A. \& J. Biggs, 2005. Spatial patterns in pond invertebrate communities: separating environmental and distance effects. Aquatic Conservation: Marine and Freshwater Ecosystems 15: 549-558.

Clausnitzer, V. \& R. Jödicke (eds), 2004. Guardians of the watershed. Global status of dragonflies: critical species, threat and conservation. International Journal of Odonatology 7: 1-430.

Collinson, N. H., J. Biggs, A. Corfield, M. J. Hodson, D. Walker, M. Whitfield \& P. J. Williams, 1995. Temporary and permanent ponds: an assessment of the effects of drying out on the conservation value of aquatic macroinvertebrate communities. Biological Conservation 74: 125-133.

Colwell, R. K., 2005. EstimateS: statistical estimation of species richness and shared species from samples. Version 7.5. User's Guide and application published at: http://purl. oclc.org/estimates.

Cottenie, K., E. Michels, N. Nuytten \& L. De Meester, 2003. Zooplankton metacommunity structure: regional vs. local processes in highly interconnected ponds. Ecology 84: 991-1000.

De Meester, L., S. Declerck, R. Stoks, G. Louette, F. Van de Meutter, T. De Bie, E. Michels \& L. Brendonck, 2005. Ponds and pools as model systems in conservation biology, ecology and evolutionary biology. Aquatic Conservation: Marine and Freshwater Ecosystems 15: 715-725.

Delarze, R., Y. Gonseth \& P. Galland, 1998. Guide des milieux naturels de Suisse. Delachaux et Niestlé, Lausanne.

Delucchi, C. M., 1989. Movement patterns of invertebrates in temporary and permanent streams. Oecologia 78: 199-207.

Foggo, A., S. D. Rundle \& D. T. Bilton, 2003. The net result: evaluating species richness extrapolation techniques for littoral pond invertebrates. Freshwater Biology 48: 17561764.

Gaston, K. J., 2000. Global patterns in biodiversity. Nature 405: 220-227.

Gaston, K. J. \& J. I. Spicer, 2004. Biodiversity. An Introduction, 2nd edn. Blackwell Science Ltd, Malden, Oxford, Victoria.

Gurung A. B. (ed.), 2005. GLOCHAMORE Global Change and Mountain Regions. Research Strategy. Mountain Research Initiative, Bern.

Hinden, H., 2004. La biodiversité des petits plans d'eau alpins de Suisse. MS these, University of Geneva, Geneva.

Hinden, H., B. Oertli, N. Menetrey, L. Sager \& J.-B. Lachavanne, 2005. Alpine pond biodiversity: what are the related environmental variables? Aquatic Conservation: Marine and Freshwater Ecosystems 15: 613-624.

Hodkinson, I. D. \& J. K. Jackson, 2005. Terrestrial and aquatic invertebrates as bioindicators for environmental monitoring, with particular reference to mountain ecosystems. Environmental Management 355: 649-666.

Illies, J., 1978. Limnofauna Europaea, 2nd edn. Gustav Fischer Verlag, Stuttgart.

Jeffries, M., 1988. Measuring talling element of chance in pond populations. Freshwater Biology 20: 383-393.

Jeffries, M., 2005. Small ponds and big landscapes: the challenge of invertebrate spatial and temporal dynamics for European pond conservation. Aquatic Conservation: Marine and Freshwater Ecosystems 15: 541-548.

Körner, C., 2001. Alpine ecosystems. In Levin, S. A. (ed.), Encyclopedia of Biodiversity. Academic Press, San Diego, 133-144.

Logue, J. B., C. T. Robinson, C. Meier \& J. R. Van der Meer, 2004. Relationship between sediment organic matter, bacteria composition, and the ecosystem metabolism of alpine streams. Limnology and Oceanography 49: 2001-2010.

Magurran, A. E., 2003. Measuring Biological Diversity. Blackwell Publishing, Oxford.

Maibach, A. \& C. Meier, 1987. Atlas de distribution des libellules de Suisse (Odonata). Centre Suisse de 
Cartographie de la Faune, Ligue suisse pour la protection de la nature, Neuchâtel.

Matthaei, S., 2003. Expansion contraction cycle of a stream/ lake network in a high alpine floodplain. Diploma thesis, Swiss Federal Institute of Environmental Science and Technology, Dübendorf, Switzerland.

Oertli, B., D. Auderset Joye, E. Castella, R. Juge \& J-B. Lachavanne, 2000. Diversité biologique et typologie écologique des étangs et petits lacs de Suisse. Rapport final. OFEFP et Université de Genève.

Oertli, B., D. Auderset Joye, E. Castella, R. Juge, D. Cambin \& J.-B. Lachavanne, 2002. Does size matter? The relationship between pond area and biodiversity. Biological Conservation 104: 59-70.

Oertli, B., D. Auderset Joye, E. Castella, R. Juge, A. Lehmann \& J.-B. Lachavanne, 2005a. PLOCH: a standardised method for sampling and assessing the biodiversity in ponds. Aquatic Conservation: Marine and Freshwater Ecosystems 15: 665-679.

Oertli, B., J. Biggs, R. Céréghino, P. Grillas, P. Joly \& J.-B. Lachavanne, 2005b. Conservation and monitoring of pond biodiversity: introduction. Aquatic Conservation: Marine and Freshwater Ecosystems 15: 535-540.

Rey, P. \& P. Pitsch, 2004. Die Entdeckung der Bescheidenheit: erste Einblicke in das Leben der Fische auf Macun. Cratschla 2: 23.

Robinson, C. T. \& B. Kawecka, 2005. Benthic diatoms of an Alpine stream/lake network in Switzerland. Aquatic Sciences 67: 492-506.

Robinson, C. T. \& S. Matthaei, 2007. Hydrological heterogeneity of an Alpine stream/lake network in Switzerland. Hydrological Processes 21: 3146-3154.

Rosenzweig, M. L., W. R. Turner, J. G. Cox \& T. H. Ricketts, 2003. Estimating diversity in unsampled habitats of a biogeographical province. Conservation Biology 17: 864874.

Ruegg, J. \& C. T. Robinson, 2004. Comparison of macroinvertebrate assemblages of permanent and temporary streams in an Alpine flood plain, Switzerland. Archiv für Hydrobiologie 161: 489-510.

Schanz, F., 1984. Chemical and algological characteristics of five high mountain lakes near the Swiss National Park. Verhandlungen Internationale Vereinigung für theoretische und angewandte Limnologie 22: 1066-1070.

Scheurer, T., 2004. Global change research in mountain biosphere reserves: Swiss National Park biosphere reserve. In Lee, C. \& T. Schaaf (eds), Global Change Research in Mountain Biosphere Reserves. Proceedings of the International Launching Workshop, Entlebuch Biosphere Reserve, Switzerland, 10-13 November 2003. UNESCO, Paris, 85-92.

Schneider, D. W., 1999. Influence of hydroperiod on invertebrate community structure. In Batzer, D. P., R. R. Rader \& S. A. Wissinger (eds), Invertebrates in Freshwater Wetlands of North America: Ecology and Management. Wiley, New York, 299-318.

Soderstrom, O., 1987. Upstream movements of invertebrates in running waters-a review. Archiv für Hydrobiologie 111: 197-208.
Sommaruga, R., R. Psenner, E. Schafferer, K. A. Koinig \& S. Sommaruga-Wograth, 1999. Dissolved organic carbon concentration and phytoplankton biomass in high-mountain lakes of the Austrian Alps: potential effect of climatic warming an UV underwater attenuation. Arctic Antarctic and Alpine Research 31: 247-253.

Sommaruga-Wograth, S., K. A. Koinig, R. Schmidt, R. Sommaruga, R. Tessadri \& R. Psenner, 1997. Temperature effects on the acidity of remote alpine lakes. Nature 387 : 64-67.

Stoll, A., 2005. Mise en place d'un monitoring de la biodiversité des étangs de Macun (Parc National Suisse, GR). Travail de diplôme. University of Applied Sciences of Western Switzerland, EIL, Lullier.

Tachet, H., P. Richoux, M. Bournaud \& P. Usseglio-Polatera, 2000. Invertébrés d'eaux douces. Systématique, biologie, écologie. CNRS Editions, Paris.

Theurillat, J. P. \& A. Guisan, 2001. Potential impact of climate change on vegetation in the European Alps: a review. Climatic Change 50: 77-109.

Thomas, C. D., A. Cameron, R. E. Green, M. Bakkenes, L. J. Beaumont, Y. C. Collingham, B. F. N. Erasmus, M. F. de Siqueira, A. Grainger, L. Hannah, L. Hughes, B. Huntley, A. S. van Jaarsveld, G. F. Midgley, L. Miles, M. A. Ortega-Huerta, A. T. Peterson, O. L. Phillips \& S. E. Williams, 2004. Extinction risk from climate change. Nature 427: 145-148.

Thuillier, W., S. Lavorel, M. B. Araújo, M. T. Sykes \& I. C. Prentice, 2005. Climate change threats to plant diversity in Europe. Proceedings of the National Academy of Sciences of the United States of America 102: 8245-8250.

Van de Meutter, F., R. Stoks \& L. De Meester, 2006. Lotic dispersal of lentic macroinvertebrates. Ecography 29: 223-230.

Väre, H., R. Lampinen, C. Humphries \& P. Williams, 2003. Taxonomic diversity of vascular plants in the European alpine areas. In Nagy, L., G. Grabherr, C. Körner \& D. B. A. Thompson (eds), Alpine Biodiversity in Europe-A Europe-wide Assessment of Biological Richness and Change. Springer, 133-148.

Wathne, B. M. \& H. H. Hansen, 1997. MOLAR. Measuring and modelling the dynamic response of remote mountain lake ecosystem to environmental change: a program of Mountain lake Research. MOLAR Project Manual. NIVA Report 0-96061, Oslo.

Wiggins, G. B., R. J. Mackay \& I. M. Smith, 1980. Evolutionary and ecological strategies of animals in annual temporary pools. Archiv für Hydrobiologie Supplement 58: 97-206.

Williams, D. D., 1987. The Ecology of Temporary Waters. Croom Helm, London \& Sydney.

Wissinger, S. A., A. J. Bohonak, H. H. Whiteman \& W. S. Brown, 1999. Subalpine wetlands in central Colorado: habitat permanence, salamander predation, and invertebrate communities. In Batzer, D. P., R. R. Rader \& S. A. Wissinger (eds), Invertebrates in freshwater wetlands of North America: ecology and management. Wiley, New York, 757-790. 